\title{
Automation of choosing hot and cold pixels process in the estimate of the sensitive heat flow and evapotranspiration
}

Characterize accurately and accurate evapotranspiration (ET) on a global scale has been one of the major determinant challenges in terrestrial ecosystem studies, climate dynamics and hydrological cycle. The goal in this study was to evaluate methodologies presented in the literature proposing a new methodology and automation in the process of selection of hot and cold pixels to need the sensible heat flux $\mathrm{H}$ and ET. The study was conducted in four different locations in the state of Mato Grosso, Brazil. And two areas of forest and two formed by pasture. For the $\mathrm{H}$ automation process we used the proposed Bastiaanssen et al. (1998a), Gao et al. (2011), and other vegetation using different levels of the literature suggests. The automation of the selection of hot and cold pixels process was successful, showing correlations above 0.83 for the estimates of $\mathrm{H}$ and 0.75 for estimates of ET. The identification of hot and cold pixels using the methodology by similarity of neighboring pixels using the average of pixels showed the highest correlations to the $\mathrm{H}$ in the study areas. LAl had the best indicator in the automated identification of hot and cold pixels to estimate the daily evapotranspiration (ET24h).

Keywords: Automation; Sensible Heat Flux; Remote Sensing.

\section{Automação do processo de escolha de pixels quentes e frios na estimativa do fluxo de calor sensível e evapotranspiração}

\begin{abstract}
Caracterizar com precisão e exatidão a evapotranspiração (ET) em escala global tem sido um dos maiores desafios determinantes nos estudos de ecossistemas terrestres, dinâmica climática e ciclo hidrológico. O objetivo neste estudo foi avaliar metodologias apresentadas na literatura propondo uma nova metodologia e automação no processo de seleção de pixels quentes e frios que necessitam do fluxo de calor sensível $\mathrm{H}$ e ET. O estudo foi realizado em quatro locais diferentes do estado de Mato Grosso, Brasil. E duas áreas de mata e duas formadas por pastagem. Para o processo de automação $\mathrm{H}$ utilizamos a proposta de Bastiaanssen et al. (1998a), Gao et al. (2011), e outra vegetação usando diferentes níveis da literatura sugere. A automação do processo de seleção de pixels quentes e frios foi bem sucedida, apresentando correlações acima de 0,83 para as estimativas de $\mathrm{H}$ e 0,75 para as estimativas de ET. A identificação de pixels quentes e frios utilizando a metodologia por similaridade de pixels vizinhos utilizando a média de pixels apresentou as maiores correlações com o $\mathrm{H}$ nas áreas de estudo. $\mathrm{O}$ LAl apresentou o melhor indicador na identificação automatizada de pixels quentes e frios para estimar a evapotranspiração diária (ET24h).
\end{abstract}

Palavras-chave: Automação; Fluxo de calor sensível; Sensoriamento remoto.

Topic: Tecnologia, Modelagem e Geoprocessamento

Reviewed anonymously in the process of blind peer.
Received: 09/08/2020

Approved: 25/09/2020
Victor Hugo de Morais Danelichen (iD) Universidade de Cuiabá, Brasil http://lattes.cnpq.br/3461595808977435 http://orcid.org/0000-0003-4791-3301 danelichen@fisica.ufmt.br

Raphael de Souza Rosa Gomes (D) Universidade Federal de Mato Grosso, Brasil http://lattes.cnpq.br/7352154839166198 http://orcid.org/0000-0003-1591-5281 raphael@ic.ufmt.br

Josiel Maimome de Figueiredo (iD) Universidade Federal de Mato Grosso, Brasil http://lattes.cnpq.br/1242386923227672 http://orcid.org/0000-0001-8569-7684 josiel@ufmt.br

\author{
Maísa Caldas Souza Velasque (iD \\ Universidade Federal de Mato Grosso, Brasil \\ http://lattes.cnpq.br/9058961707655149 \\ http://orcid.org/0000-0002-4477-9285 \\ maisacaldas@if.ufmt.br \\ Nadja Gomes Machado (iD) \\ Instituto Federal de Mato Grosso, Brasil \\ http://lattes.cnpq.br/9058690473723423 \\ http://orcid.org/0000-0003-2113-0448 \\ nadja.machado@blv.ifmt.edu.br \\ José de Souza Nogueira (id \\ Universidade Federal de Mato Grosso, Brasil \\ http://lattes.cnpq.br/5893185001802390 \\ http://orcid.org/0000-0003-2504-7924 \\ nogueira@ufmt.br
}

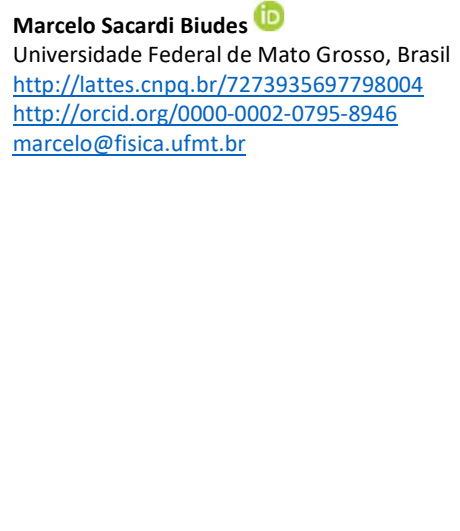

Referencing this:

DANELICHEN, V. H. M.; GOMES, R. S. R.; FIGUEIREDO, J. M.; VELASQUE, M. C. S.; MACHADO, N. G.; NOGUEIRA, J. S.; BIUDES, M. S.. Automation of choosing hot and cold pixels process in the estimate of the sensitive heat flow and evapotranspiration. Revista Ibero Americana de Ciências Ambientais, v.11, n.5, p.638-651, 2020. DOI: http://doi.org/10.6008/CBPC2179-6858.2020.005.0057 


\section{INTRODUCTION}

The Earth's water cycle influences several aspects over climate changes, meteorology, vegetable communities' dynamics (VÖRÖSMARTY et al., 1998; ZHAO et al., 2010). The water requirement to agricultural production increases a long of the world and press investment in water's supply infrastructure (VÖRÖSMARTY et al., 2010). Additionally, it has consequence on the water shortage and on the economy, which lead to develop a sustainable use of water (UN-WATER, 2008). In order to understand the water, use on agriculture, the evapotranspiration (ET) is an excellent indicator (LEIVAS et al., 2011).

The ET represents $60 \%$ of the surface water loses to the atmosphere, becoming the biggest hydrological component in global scale (MU et al., 2011). Furthermore, the ET uses more than a half of the available solar energy on the earth (RUHOFF et al., 2012). The precise and accurate ET characterization in global scale is one of the biggest challenges of the terrestrial ecosystems, climate and hydrological cycle researches (ALLEN et al., 2011). On the one hand, the precise local ET can be estimated by micrometeorological methods, and on the other hand, remote sensing methods produces good daily ET estimates in regional scales (FEILHAUER et al., 2009; ALLEN et al., 2011; ROCCHINI et al., 2012).

Several algorithms were developed to estimate ET in regional scales using remote sensing images. Most of than are energy balance (EB) based and use satellite images integrated to local meteorological data: Surface Energy Balance Algorithm for Land - SEBAL (BASTIAANSSEN et al., 1998a,b), Two - Source Model TSM (NORMAN et al., 1995), Surface Energy Balance Index - SEBI (MENENTI et al., 1993), Surface Energy Balance System - SEBS (SU, 2002), the excessive resistance - kB-1 (KUSTAS et al., 1990), Beta approximation - (CHEHBOUNI et al., 1996), Mapping Evapotranspiration at High Resolution with Internalized Calibration METRIC (ALLEN et al., 2007a,b), Simplified Surface Energy Balance - SSEB (SENAY et al., 2007; GOWDA et al., 2009) and more recently the model Surface Energy Balance with Topography Algorithm - SEBTA (GAO et al., 2011).

The land surface EB components estimated by those methods are the net radiation ( $R n)$, soil heat flux $(G)$, latent heat flux $(L E)$ and the sensible heat flux $(H)$, which is the most complex and difficult component to estimate. The correct estimation of $\mathrm{H}$ with remote sensing technique requires the correct estimation of the ground surface temperature $(T s)$, directly related to the flux near the surface (HALL et al., 1992). Since the estimation of radiometric surface temperature was possible through sensors installed on the remote platform, the estimation of land surface $\mathrm{H}$ become possible (ZIBOGNON et al., 2002). Usually, $\mathrm{H}$ is obtained by the empiric relation proposed by Monteith (1973) in the EB models (Equation 1).

$$
H=\frac{\left(T_{s}-T_{a}\right) \rho C_{p}}{r_{a h}}=\frac{\rho C_{p} d T}{r_{a h}}
$$

where $T_{s}$ is the surface temperature, $T_{a}$ is the air temperature above the surface, $\rho$ is the air density, $c_{p}$ is the calorific capacity, $r_{a h}$ is the aerodynamic resistance for heat transfer and $d T$ is the difference of temperature between two distinct height $\left(Z_{1}\right.$ and $\left.Z_{2}\right)$.

The parameters $d T$ and $r_{a h}$ on the Equation (1) are unknown. The SEBAL uses two anchor pixels, a very dry (hot and dry) and a very wet (cold and wet) pixels, to estimate these parameters by iteration (BASTIAANSSEN et al., 1998a,b). The Equation (1) is used under neutral atmosphere, which needs a correction 
based on Monin-Obukhov theory (BRUTSAERT, 1982). In order to execute these procedures, the identification of two anchor pixels is usually manual, which has the disadvantage to be subjective and time consuming. Furthermore, the $\mathrm{H}$ and $\mathrm{ET}$ are highly sensible to these selections. Consequently, the dependency on the researcher attentions and expertise increase the error margin of the estimatives (KJAERSGAARD et al., 2009).

Some proposals for automatize the hot and cold pixels selection were presented, which include the use of average, median and mode of the values from surface temperature obtained by any orbital sensor (BASTIAANSSEN et al., 1998a,b). Other proposals are based on the spectral characteristics of the surface vegetation using vegetation indexes and images textures in the visible spectrum (GAO et al., 2011; MAAS et al., 2008; ALLEN et al., 2011). All these proposals of pixels selection were automatized. Thus the objective of this work was to evaluate the estimation of ET and H estimated by the SEBAL by the automatized hot and cold pixel selection.

\section{MATERIALS AND METHODS}

\section{Study Area}

The study was conducted in four different locations in the state of Mato Grosso, which have different vegetation surface and climatic characteristic (BIUDES et al., 2015). The first area is a transitional AmazonCerrado forest, located in the Macarai Farm (SINOP) with coordinates 110 24'43.4" S and 55o 19' 25.7" W and altitude $435 \mathrm{~m}$, at Sinop, Mato Grosso, Brazil. The vegetation is a Semideciduous Tropical Forest with canopy height between 22-25 m and foliar area index (LAI) varies between $2.5 \mathrm{~m}^{2} \mathrm{~m}^{-2}$ during the dry season and $6 \mathrm{~m}^{2} \mathrm{~m}^{-2}$ during the wet season (BIUDES et al., 2014). The 30-year mean annual temperature in Sinop area is $24{ }^{\circ} \mathrm{C}$ with little seasonal variation, and rainfall is approximately $2000 \mathrm{~mm}$ year ${ }^{-1}$ (VOURLITIS et al., 2011). The soil is classified as a Quartzarenic Neosol (PRIANTE FILHO et al., 2004).

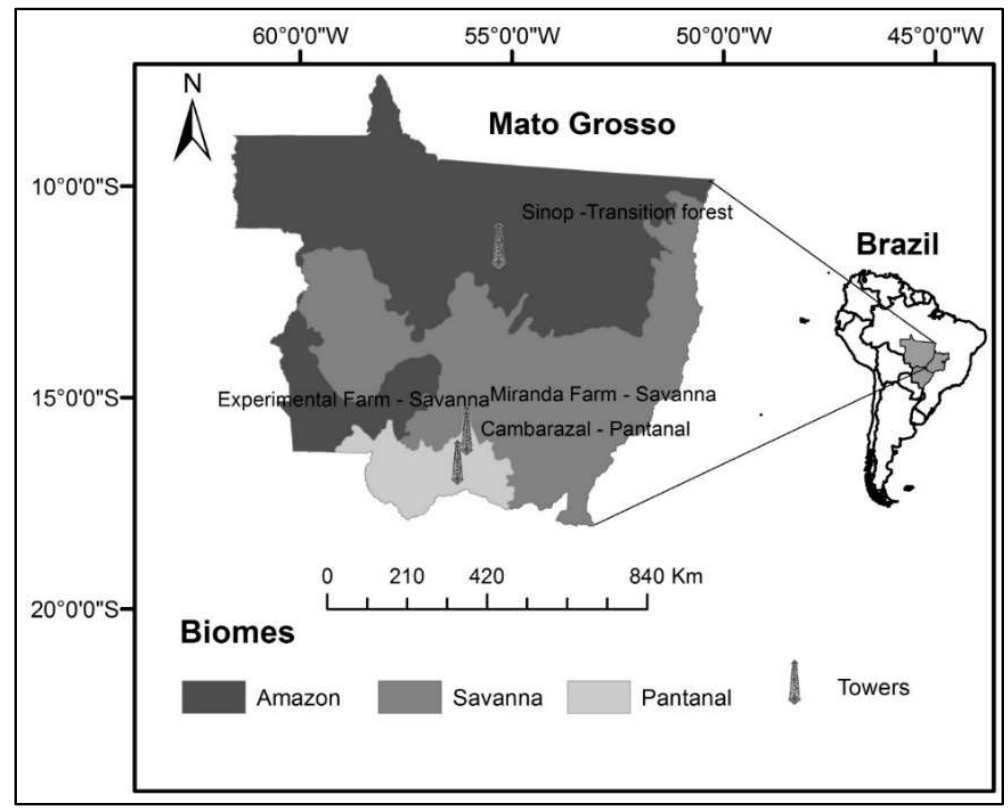

Figure 1: Location of the experimental sites, Mato Grosso, Brazil.

The three next sites have similar climatic characteristic, with average of $1200-1400 \mathrm{~mm}_{\text {year }}{ }^{-1}$ and 
25.7-26.1으 air temperature (BIUDES et al., 2012). One is located at the Miranda Farm (MF) with coordinates 1543'53.65" S and 56-04'18.88" W and altitude $157 \mathrm{~m}$, at Cuiabá, Mato Grosso, Brazil. The vegetation of the MF is a mixed woodland-grassland (locally known as campo sujo) (VOURLITIS et al., 2013). Nearby, another study site was in a non-native grassland located at the Experimental Farm (EF), with coordinates 1547'11" S and 5604'47" W and altitude 140m, at Santo Antônio do Leverger, Mato Grosso, Brazil. This area is characterized by a pasture of Brachiaria humidicola (BIUDES et al., 2009; BIUDES et al., 2012). The soil of the region of the two sites is rocky, dystrophic red-yellow Latosol (RADAMBRASIL, 1982).

The third area is located in the Reserva Particular do Patrimônio Natural SESC Pantanal (CAM) with coordinates 1639'50" S and 5647'50" W and altitude $120 \mathrm{~m}$, at of Barão de Melgaço, Mato Grosso, Brazil. This area presents a dominance of Cambará trees (Vochysia divergens Pohl), with canopy height between 28 and $30 \mathrm{~m}$ in a continue range of $25 \mathrm{~km}$ of extension and $4 \mathrm{~km}$ of width, parallel of the Cuiaba river. The soil was classified as Gleyic Solonetz (ZEILHOFER et al., 2006).

\section{Micrometeorological measurements}

The net radiation was measured by a radiometer balance equipment (Net Radiometer, Kipp \& Zonen Delft, Inc., Holland), and the incident solar radiation incidence by a pyranometer (LI-200, Campbell Sci, Inc., USA) both installed over $42 \mathrm{~m}$ in SINOP, $2.5 \mathrm{~m}$ in MF and EF and $33 \mathrm{~m}$ in CAM. The soil heat flux was measured by soil heat flux plates (HFT-3.1, REBS Inc., Seattle, Washington) installed at $2 \mathrm{~cm}$ depth. The air temperature and water vapor pressure gradients were estimated by two thermo-hygrometers (HMP 45 C, Vaisala, Inc., Helsinki, Finland) installed at 39 and $45 \mathrm{~m}$ in SINOP, 5 and $18 \mathrm{~m}$ in MF, 0.5 and $1.8 \mathrm{~m}$ in EF and 33.7 and 37.7 $m$ in CAM.

\section{Energy Balance Estimates by Bowen Ratio Method}

Evapotranspiration (ET) and sensible heat flux $(\mathrm{H})$ estimates were calculated using the Bowen ratio energy balance method (BREB). The BREB method has been widely used since it was proposed in 1926 because it has the advantages of a clear physical concept, few parameter requirements, and a simple calculation method (HU et al., 2013). The comparison of LE and H obtained with BREB method and eddy covariance method have shown that the BREB provides accurate and reliable values, and that instrument drifts on sub-annual time scales are minimal (DREXLER et al., 2004; BIUDES et al., 2009; BILLESBACH et al., 2012; DICKEN et al., 2013; RODRIGUES et al., 2013). The BREB method we used to follow the guidelines and modification described by Perez et al. (1999). Average fluxes of LE and H were calculated by Equations (2) and (3), respectively, at 30-min averaging intervals.

$$
\begin{aligned}
& L E=\frac{R n-G-\Delta S}{1+\beta} \\
& H=\frac{R n-G-\Delta S}{1+\beta^{-1}}
\end{aligned}
$$

where $L E$ and $H$ is the latent and sensible heat flux $\left(\mathrm{W} \mathrm{m}^{-2}\right), \mathrm{Rn}$ is the net radiation $\left(\mathrm{W} \mathrm{m}^{-2}\right), \mathrm{G}$ is the ground heat flux $\left(\mathrm{W} \mathrm{m}^{-2}\right)$, and $\Delta S$ is the heat storage in the canopy air space and biomass calculated using the 
parameterization proposed by Moore et al. (1986). The $\Delta S$ was calculated every 30 min at SIN and CAM, but was negligible at MF and EF due to the low vegetation density. $\beta$ is the Bowen ratio defined by Equation (4):

$\beta=\left(\frac{C_{p}}{\lambda 0.622}\right)\left(\frac{\Delta T}{\Delta e}\right)$

where $C_{p}$ is the specific heat at constant pressure $\left(1.00467 \mathrm{~J} \mathrm{~g}^{-1} \mathrm{~K}^{-1}\right), 0.622$ is the ratio of molecular weights of water and air, and $\Delta T$ and $\Delta e$ are the difference of temperature $\left({ }^{\circ} \mathrm{C}\right)$ and water vapor pressure $(\mathrm{kPa})$ between the two measurement levels, respectively. The latent heat of vaporization $\left(\lambda ; \mathrm{J} \mathrm{g}^{-1}\right)$ defined by Equation (5).

$\lambda=1.919 \times 10^{6}\left(\frac{T+273.16}{(T+273.16)-33.91}\right)^{2}$

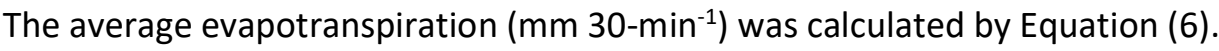

$E T=\frac{L E}{\lambda}$

The daily evapotranspiration was obtained as the sum of 48 values of evapotranspiration at $30-\mathrm{min}$ averaging intervals. The criteria for accepting/rejecting data collected from the BREB method were based on those described by Perez et al. (1999) and revised by Hu et al. (2013). It was assumed that the gradients were sufficient in each experimental area due to the large fetches over relatively homogeneous terrain. The BREB method fails when (1) sensor resolution is inadequate to resolve gradients in $\Delta T$ and $\Delta e$ (UNLAND et al., 1996), (2) stable atmospheric conditions, such as during the dawn and dusk, cause $\beta \approx-1$ (ORTEGA-FARIAS et al., 1996) and the evapotranspiration tends to infinity, and (3) conditions change abruptly leading to errors in measurement (PEREZ et al., 1999). Using this filtering method, physically realistic values of $\beta$ can be obtained in an objective, quantitative manner, which limits the potential for bias and error in estimating energy balance terms (PEREZ et al., 1999; HU et al., 2013).

\section{Pre-processing of TM Landsat 5 images}

The 95 images Thematic Mapper (TM) Landsat 5 used in this work were acquired from National Institute of Spatial Research (INPE) ${ }^{1}$. A subset of 28 images are related to SINOP in path/row 226/68 obtained during 2005 to 2008; 38 images are related to MF and EF in path/row 226/71 obtained from 2007 to 2010 and finally 29 images are related to CAM in path/row 226/72 obtained during 2007 to 2010 . The main criteria used to choose these images was the absolutely no clouds around the experimental sites, which permitted high accuracy of the results. Each image bands were stacked and orthorectified based on a reference image obtained in landsat ${ }^{2}$.

\section{Energy Balance Estimates by SEBAL}

The surface energy balance was estimated using Surface Energy Balance Algorithm for Land (SEBAL) technique, which use few meteorological data and satellite images obtained by orbital sensors (BASTIAANSSEN et al., 1998a; BASTIAANSSEN, 2000; ALLEN et al., 2011). The net radiation (Rn) was estimated by Equation (7)

\footnotetext{
${ }^{1}$ http://www.dgi.inpe.br/CDSR/

2 http://www.landsat.org.
} 


$$
R_{s \downarrow}\left(1-\alpha_{\text {sup }}\right)-R_{L \uparrow}+\varepsilon_{0} R_{L \downarrow}
$$

where, $R_{s \downarrow}$ is the instantaneous incident solar radiation ( $\left.\mathrm{W} \mathrm{m}^{-2}\right)$, $\alpha_{\text {surf }}$ is the surface albedo (dimensionless), $R\llcorner\downarrow$ is the instantaneous long wave radiation emitted by the atmosphere $\left(\mathrm{W} \mathrm{m}^{-2}\right), R_{L} \uparrow$ is the instantaneous long wave radiation emitted by the surface $\left(\mathrm{W} \mathrm{m}^{-2}\right)$ and $\varepsilon_{0}$ is the atmospheric emissivity (dimensionless).

The instantaneous $\mathrm{G}$ was obtained by the Equation (8) (BASTIAANSSEN, 2000).

$$
G=R n\left(T_{s}-273.16\right)(0.0038+0.0074 \alpha)\left(1-0.98 \mathrm{NDVI}^{4}\right)
$$

where Ts is the surface temperature (K) and NDVI is the vegetation index of the normalized difference (dimensionless). In order to correct the $G$ values for water areas (NDVI $<0$ ), we used the expression $G=0.3 R n$ (ALLEN et al., 2002).

The sensible heat flux $(H$, Equation 9) was estimated based on wind speed and air temperature difference $(d T)$, between two levels near the surface $\left(z_{1}=0.1 \mathrm{~m}\right.$ and $\left.z_{2}=2 \mathrm{~m}\right)$ (BASTIAANSSEN et al., 1998a; ALLEN et al., 2007a,b). The main assumption in SEBAL is the linear relation between the air temperature difference (dT) and the land surface temperature $\left(T_{\text {sup }}\right)$, i.e. $d T=a+b T_{\text {sup }}$, obtained by interaction, where the calibration constants $a$ and $b$ require, for their determination, the identification of two reference pixels (anchors pixels), that represent extremes values of temperature and humidity, called hot and cold pixels. In this work, the cold pixel was located in a spot of water bodies (Cuiabá river, lakes, little rivers), which assume $\mathrm{H}=0$ and $\mathrm{LE}=\mathrm{Rn}-\mathrm{G}$ (BASTIAANSSEN et al., 1998a). The hot pixel was chosen in bare soil area, which assume $\mathrm{LE}=0$ and $\mathrm{H}=\mathrm{Rn}-\mathrm{G}$ (BASTIAANSSEN et al., 1998a; MENDONÇA et al., 2012). The initial $\mathrm{H}$ values only serve as input parameters in an iterative process, which stopped when the coefficient of Monin-Obukhov was 0.001 (BASTIAANSSEN et al., 1998a; MENDONÇA et al., 2012).

$$
H=\frac{\left(\rho C_{p} d T\right)}{r_{a}}
$$

where $\rho$ is air density $\left(\mathrm{kg} \mathrm{m}^{-3}\right), C_{\mathrm{p}}$ is specific air heat $\left(1004 \mathrm{~J} \mathrm{~kg}^{-1} \mathrm{~K}^{-1}\right), \mathrm{dT}(\mathrm{K})$ is the air temperature difference between two levels, and $r_{a}$ is the aerodynamic resistance to heat transport ( $\mathrm{s} \mathrm{m}-1$ ). The location of anchors pixels (hot and cold) require foreknowledge of the area being studied and the researcher must look for proper choice of these targets. The instantaneous latent heat flux (LE) was estimated by the energy balance equation (Equation 1) and the daily latent heat flux ( $\left.\mathrm{LE}_{24 \mathrm{~h}}\right)$ was estimated by Equation (10).

$$
L E_{24 h}=F E_{i} R n_{24 h}
$$

where $\mathrm{FE}_{\mathrm{i}}$ is the instantaneous evaporative fraction (Equation 11$)$ and $\mathrm{Rn}_{24 \mathrm{~h}}$ is the daily net radiation $\left(\mathrm{W} \mathrm{m}^{-2}\right)$ estimated

$$
F E_{i}=\left(\frac{L E}{R n-G}\right)=F E_{24 h}=\frac{L E_{24 h}}{R n_{24 h}}
$$

$R n_{24 h}=R s_{24 h}(1-\alpha)-110 \tau_{24 h}$

where $\mathrm{FE}_{24 \mathrm{~h}}$ is the daily evaporative fraction, that was equalized to FEi (BASTIAANSSEN, 2000; ALLEN et al., 2011), Rs24h is the daily incident solar radiation $\left(\mathrm{W} \mathrm{m}^{-2}\right.$ ) and $\tau_{24 h}$ is the daily atmospheric transmissivity (ALLEN et al., 2002). The

$$
E T_{24 h}=\frac{\left(L E_{24 h} \times 86,4\right)}{2450}
$$

\section{Proposed automatized hot and cold pixels choice}

\section{Bastiaanssen et al. (1998a)'s proposal}

According to Bastiaanssen et al. (1998a) the linear relationship between $\mathrm{T}_{\text {sup }}$ and $\mathrm{dT}$ would be better 
represented by the selection of two pixels with extreme temperatures: one pixel with maximum temperature (hot pixel); and one pixel with minimum temperature (cold pixel).

\section{Gao et al. (2011)'s proposal}

The Gao et al. (2011)'s proposal is based on a linear a combination of modified soil adjusted vegetation index (MSAVI) and land surface temperature $\left(T_{\text {sup }}\right)$, resulting in a graph that presented as a trapezoid (Figure 2). Where the $\mathrm{x}$ axis represents MSAVI and y axis represents Ts. So, the pixels are chosen as the two extreme points of the trapezium (upper left and lower right). The purpose of this methodology is to choose the hot pixel as the one with lower MSAVI and higher $\mathrm{T}_{\text {sup }}$, and the cold pixel with highest MSAVI and lowest Ts.

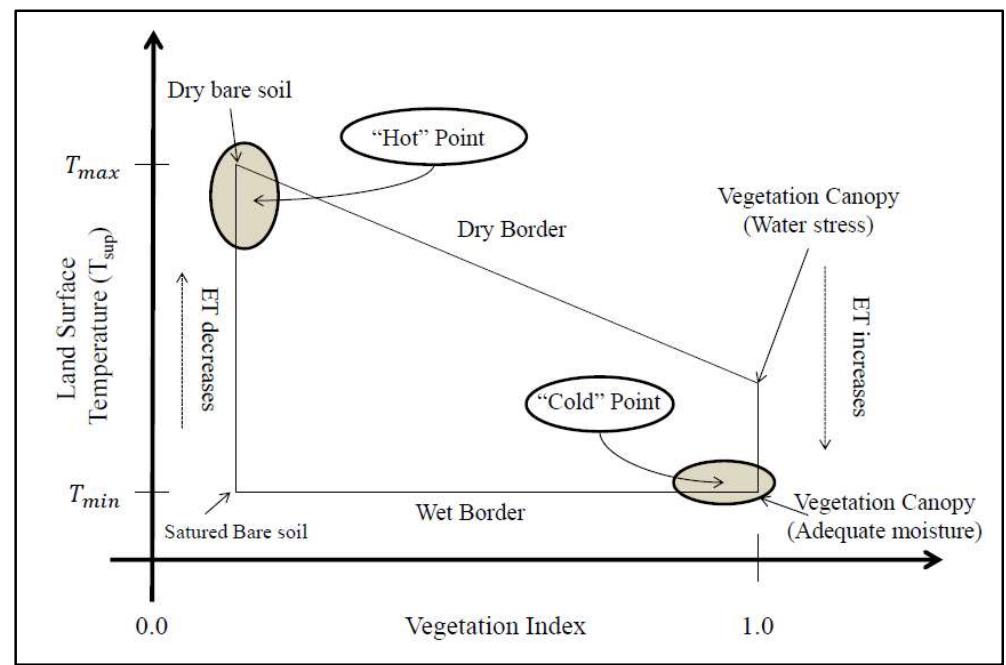

Figure 2: Schematic structure of the trapezium to identify the hot and cold pixel. The abscissa is related to vegetation indexes (NDVI, SAVI, LAI and MSAVI) pixels and the vertical axis is the surface temperature ( $T_{\text {sup }}$ ).

\section{Other proposals}

Based on the proposal of Gao et al. (2011), we used the soil adjusted vegetation index (SAVI), normalized difference vegetation index (NDVI) and leaf area index (LAI) instead of MSAVI. The automation consisted to finding the extremes representative pixels of the trapezoid (Figure 2). After the selection of the hot and cold pixel, the determination of $a$ and b coefficients were performed by Bastiaanssen (1998a). We also proposed to analyze the pixels around (NDVI around, $\mathrm{LAl}$ around, SAVI around, MSAVlaround) the selected hot and cold pixels, that represent $90 \%$ of similarity of the central pixel selected (Figure 3 ). Thus, the average of the nine hot and cold pixels was used to estimate $a$ and $b$ coefficient.

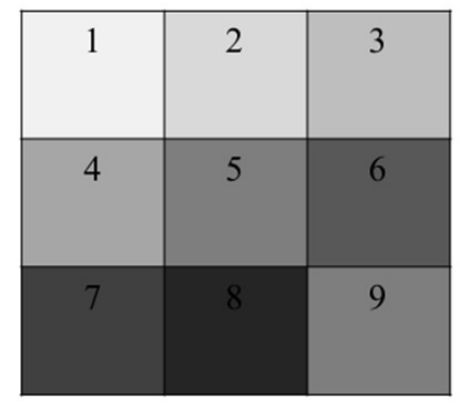

Figure 3: Region utilized around the central pixel, represented by de number 5. 


\section{RESULTS AND DISCUSSION}

\section{Sensible heat flux estimated by different proposes}

Daily $\mathrm{H}$ estimated based on choices of hot and cold pixels showed variation in different soil covers, with an average of $12.47 \mathrm{~W} \mathrm{~m}^{2}$, in all areas and among the entire study period. The minimum value of 2.66

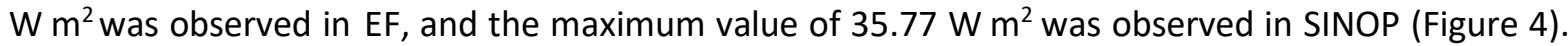

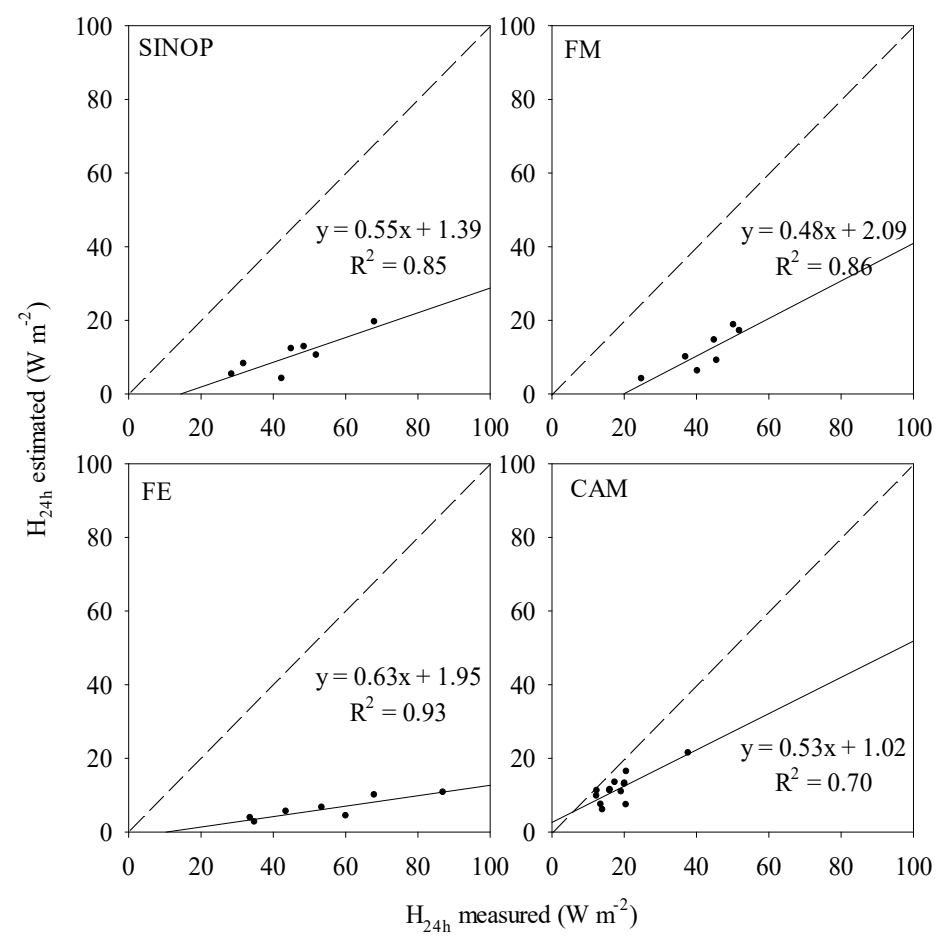

Figure 4: Relationship between measured sensible heat flux $\left(\mathrm{H}_{24 \mathrm{~h}}\right.$ measured) and estimated by SEBAL $\left(\mathrm{H}_{24 \mathrm{~h}}\right.$ estimated) on transitional Amazon-Cerrado forest (SINOP), Miranda Farm (MF), Experimental Farm (EF) and Cambará (CAM).

It is noticed that the measured daily $\mathrm{H}$ showed biggest values for pastures region (EF and MF) and smallest in monodominant forest areas and transition forest (CAM and SINOP), while the reverse happened with estimates of daily $\mathrm{H}$ with the automated selection of pixels. This fact can be explained based on the thermal band (band 6) of Landsat - 5, which have a spatial resolution of $120 \mathrm{~m}$, and the estimate of $\mathrm{H}_{24 \mathrm{~h}}$ by empirical equation Monteith (1973) takes the surface temperature into account. However, the temperature used in this equation and in all energy balance algorithms that use data from satellite sensors formulated so far (SEBAL, TSM, SEBI, SEBS, approximation Beta - $\beta$, METRIC, SSEB e SEBTA), without exception, using radiometric temperature as the surface temperature (ZHAN et al., 1996; ZIBOGNON et al., 2002). Radiometric temperature is known to depend on the viewing angle of each orbital sensor and cannot relate to the surface temperature, which is dependent on the turbulent fluxes through the canopy and dynamic biosphere (ZHAN et al., 1996; ZIBOGNON et al., 2002). Temperature dependent of turbulent flow is commonly referred to aerodynamic surface temperature, thus the precise surface temperature is poorly defined, and therefore the estimates $H$ remote sensing are problematic (ZIBOGNON et al., 2002).

Daily sensible heat flux $\left(\mathrm{H}_{24 h}\right)$ estimated based on the automatized identification of hot and cold pixels 
by vegetation indexes that showed better performance (considering here the higher determination coefficients), was NDVI for CAM, SAVI for EF, NDVIaround for MF e Bastiaanssen's proposal for SINOP (Figure 4).

In the pastures and monodominant forest, estimates of $\mathrm{H}$ were influenced by vegetation indexes (NDVI and SAVI), while in the forest transition (SINOP) H correlated better with the surface temperature (proposed Bastiaanssen). In area monodominant forest (CAM) the daily sensible heat flux estimated based on the proposal of NDVI among the proposals showed the highest R - squared of 0.63, MAE of $3.12 \mathrm{~W} / \mathrm{m}^{2}$, the RMSE $15.40 \mathrm{~W} / \mathrm{m}^{2}$ and correlation of 0.72 . In EF the daily sensible heat flux estimated based on the proposal of the SAVI showed between proposals presented, the highest coefficient of determination 0.78 , MAE of $46.73 \mathrm{~W} / \mathrm{m}^{2}$, RMSE of $55.21 \mathrm{~W} / \mathrm{m}^{2}$ and correlation of 0.78 . In MF the $\mathrm{H}$ based on the proposal presented NDVlaround among the proposals the largest R - squared of $0.72, \mathrm{MAE}$ of $41.83 \mathrm{~W} / \mathrm{m}^{2}$, RMSE of $43.58 \mathrm{~W} / \mathrm{m}^{2}$ and a correlation of 0.71 . In SINOP the daily sensible heat flux estimated based on the proposal presented Bastiaanssen showed the largest R - squared of 0.72 additionally's proposal showed a MAE of 15.75 $\mathrm{W} / \mathrm{m}^{2}$, RMSE of $35.77 \mathrm{~W} / \mathrm{m}^{2}$ and correlation of 0.83 (Figure 4, Table 1 ).

Table 1: Root mean square error (RMSE), mean absolute error (MAE) and Spearman correlation of daily sensible heat flux $\left(\mathrm{H}_{24 \mathrm{~h}}\right)$ measured in the experimental sites and estimated by SEBAL using the different automation proposes (Bastiaanssen, mSAVI around, NDVI around, SAVI around, LAI around, mSAVI, NDVI, SAVI e LAI). * $p<0.05$

\begin{tabular}{|c|c|c|c|c|c|c|c|c|c|c|c|c|}
\hline Proposes & SINOP & & & MF & & & $\mathrm{EF}$ & & & CAM & & \\
\hline & RMSE & MAE & $r$ & RMSE & MAE & $r$ & RMSE & MAE & $r$ & RMSE & MAE & $r$ \\
\hline Bastiaanssen & 35.77 & 15.75 & 0.82 & 43.91 & 42.26 & 0.71 & 55.51 & 47.29 & $0.92 *$ & 14.68 & 4.68 & $0.69 *$ \\
\hline $\begin{array}{l}\text { MSAVI } \\
\text { around }\end{array}$ & 35.06 & 16.84 & 0.60 & 43.02 & 41.31 & 0.77 & 55.61 & 47.48 & 0.71 & 15.40 & 5.45 & $0.83 *$ \\
\hline $\begin{array}{l}\text { NDVI } \\
\text { around }\end{array}$ & 35.31 & 14.71 & 0.20 & 43.59 & 41.84 & 0.71 & 55.52 & 47.15 & $0.78^{*}$ & 14.47 & 4.26 & $0.67 *$ \\
\hline $\begin{array}{l}\text { SAVI } \\
\text { around }\end{array}$ & 34.76 & 16.19 & 0.77 & 43.09 & 41.43 & $0.88^{*}$ & 55.46 & 47.32 & $0.82 *$ & 15.30 & 6.05 & $0.80^{*}$ \\
\hline $\begin{array}{l}\text { LAI } \\
\text { around }\end{array}$ & 35.81 & 19.10 & -0.14 & 43.87 & 42.41 & $0.94 *$ & 56.04 & 47.84 & 0.60 & 16.93 & 6.55 & $0.66^{*}$ \\
\hline MSAVI & 35.00 & 13.51 & $0.82^{*}$ & 41.99 & 39.79 & 0.60 & 55.00 & 46.50 & $0.92 *$ & 15.68 & 2.97 & 0.35 \\
\hline NDVI & 35.33 & 13.57 & 0.48 & 42.32 & 40.38 & 0.71 & 55.22 & 46.71 & $0.85^{*}$ & 15.40 & 3.12 & $0.72 *$ \\
\hline SAVI & 35.29 & 13.47 & 0.54 & 41.71 & 39.35 & 0.60 & 55.21 & 46.73 & $0.85^{*}$ & 14.70 & 3.25 & 0.61 \\
\hline LAI & 36.64 & 10.78 & 0.48 & 42.37 & 39.81 & 0.25 & 55.20 & 46.62 & $0.85 *$ & 14.67 & 4.04 & 0.38 \\
\hline
\end{tabular}

Considering only the correlation index as an indicator of proximity of estimated with measured values $H_{24 h}$, values the highest correlations are found in the proposals for MSAVI around $_{\text {CAM }}(r=0.83), E F(r=0.92)$, SINOP (0.82) LAlaround for MF $(r=0.94)$ with $p-$ value $<0.05$ (Table 1). It is observed that the vegetation indexes (MSAVlaround and LAlaround) subscript 'around' (means the pixels around the central pixel) showed higher correlations for $\mathrm{H}$, which highlights the importance of the neighboring pixels on the central pixel. The $3 \times 3$ pixel grid tells us how strong candidate for hot and cold pixel is the center pixel, and how much less error in admitting the similarity of neighboring pixels.

\section{Evapotranspiration estimated by different proposes}

The daily evapotranspiration ( $\mathrm{ET}_{24 \mathrm{~h}}$ ) estimated based on automated identification of hot and cold 
pixels, which showed better performance (higher coefficients of determination) in fields of study, were estimated according to the choices of pixels through LAI parameter in CAM, EF and MF, while in the transition forest SINOP the NDV I showed better performance when compared with the measured data of daily evapotranspiration (Figure 5).

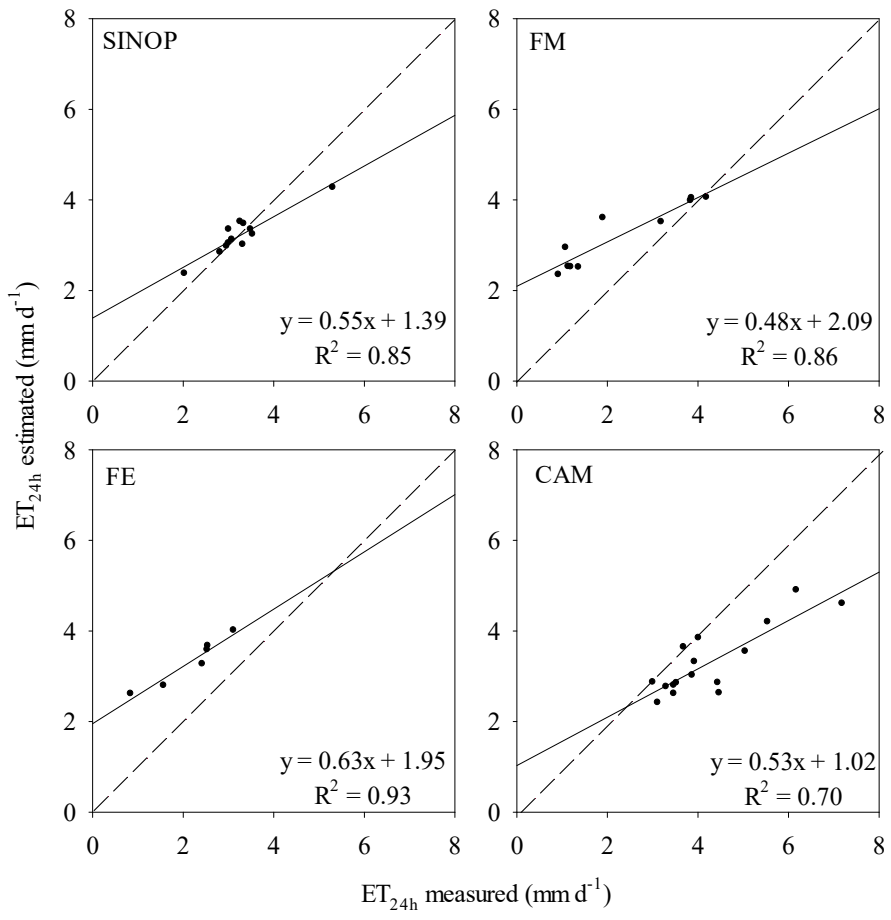

Figure 5: Relationship between measured evapotranspiration (ET24h measured) and estimated by SEBAL (ET24h estimated) on transitional Amazon-Cerrado forest (SINOP), Miranda Farm (MF), Experimental Farm (EF) and Cambará (CAM).

In CAM, EF and MF $\mathrm{ET}_{24 \mathrm{~h}}$ estimated based on the proposed LAl presented among the other, the highest coefficients of determination. In CAM 0.70, MAE of $0.44 \mathrm{~mm} /$ day, RMSE of $2.35 \mathrm{~mm} /$ day and correlation of 0.70 . In EF, R - squared of 0.93 , MAE of $0.61 \mathrm{~mm} /$ day, RMSE of $2.44 \mathrm{~mm} /$ day and correlation of 0.99. In MF, presented R-squared of 0.86 , MAE of $0.60 \mathrm{~mm} /$ day, RMSE of $1.93 \mathrm{~mm} /$ day and correlation of 0.86 . While in the forest transition SINOP the highest coefficient of determination was 0.85 , based on the proposal selection through NDVI, MAE of $1.00 \mathrm{~mm} /$ day, RMSE of $2.73 \mathrm{~mm} /$ day and correlation of 0.85 (Figure 5, table 2).

Table 2: Root mean square error (RMSE), mean absolute error (MAE) and Spearman correlation of daily evapotranspiration $\left(\mathrm{ET}_{24 \mathrm{~h}}\right)$ measured in the experimental sites and estimated by SEBAL using the different automation proposes (Bastiaanssen, mSAVI around, NDVI around, SAVI around, LAI around, mSAVI, NDVI, SAVI e LAI). * $p<0.05$

\begin{tabular}{|c|c|c|c|c|c|c|c|c|c|c|c|c|}
\hline Proposes & SINOP & & & MF & & & EF & & & CAM & & \\
\hline & RMSE & MAE & $r$ & RMSE & MAE & $r$ & RMSE & MAE & $r$ & RMSE & MAE & $r$ \\
\hline Bastiaanssen & 2.78 & 1.06 & $0.70^{*}$ & 1.95 & 0.31 & $0.75^{*}$ & 2.38 & 0.31 & $1.00^{*}$ & 2.38 & 0.04 & $0.73^{*}$ \\
\hline $\begin{array}{l}\text { MSAVI } \\
\text { around }\end{array}$ & 2.84 & 1.09 & $0.68^{*}$ & 1.96 & 0.30 & $0.75^{*}$ & 2.37 & 0.17 & $1.00^{*}$ & 2.36 & 0.08 & $0.75^{*}$ \\
\hline $\begin{array}{l}\text { NDVI } \\
\text { around }\end{array}$ & 2.77 & 1.05 & $0.67^{*}$ & 1.97 & 0.30 & $0.75^{*}$ & 2.37 & 0.32 & $1.00^{*}$ & 2.43 & 0.03 & $0.70^{*}$ \\
\hline $\begin{array}{l}\text { SAVI } \\
\text { around }\end{array}$ & 2.86 & 1.07 & $0.63^{*}$ & 1.96 & 0.30 & $0.75^{*}$ & 2.38 & 0.31 & $1.00^{*}$ & 2.38 & 0.10 & $0.74^{*}$ \\
\hline $\begin{array}{l}\text { LAI } \\
\text { around }\end{array}$ & 3.02 & 1.06 & 0.50 & 2.00 & 0.24 & $0.77^{*}$ & 2.39 & 0.40 & $1.00^{*}$ & 2.35 & 0.10 & $0.72^{*}$ \\
\hline MSAVI & 2.78 & 0.96 & $0.83^{*}$ & 1.92 & 0.37 & $0.74^{*}$ & 2.30 & 0.05 & $1.00^{*}$ & 2.36 & 0.04 & $0.70^{*}$ \\
\hline
\end{tabular}




\begin{tabular}{lllllllllllll}
\hline NDVI & 2.77 & 0.97 & $0.84^{*}$ & 1.93 & 0.35 & $0.75^{*}$ & 2.36 & 0.33 & $1.00^{*}$ & 2.35 & 0.02 & $0.71^{*}$ \\
SAVI & 2.76 & 0.96 & $0.84^{*}$ & 1.92 & 0.37 & $0.75^{*}$ & 2.32 & 0.18 & $1.00^{*}$ & 2.38 & 0.02 & $0.71^{*}$ \\
LAI & 2.49 & 1.02 & $0.74^{*}$ & 1.93 & 0.60 & $0.86^{*}$ & 2.45 & 0.61 & $1.00^{*}$ & 2.35 & 0.44 & $0.70^{*}$ \\
\hline
\end{tabular}

In the region of the transition forest the NDVI was shown to be the best indicator of the choices of hot and cold pixels, possibly because this area display heterogeneous and distinct vegetation in the same place, different from the grazing areas and areas where vegetation monodominant is not sparse (BRÉDA, 2003), which demonstrates the inefficiency of parameter LAI in determining pixel, the NDVI, in turn is the most widely used index in studies related to vegetation cover, since it allows to evaluate the conditions of vegetation and their respective dynamic spatiotemporal (HUETE et al., 1999). It is more sensitive to the presence of pigments that act on the photosynthetic processes specific to the content of chlorophyll (HUETE et al., 1997; 2002). However, an inherent feature to the NDVI is the asymptotic saturation, which makes less sensitive the detection of variations of green biomass under conditions of high rates of leaf area that this case falls within the areas of pasture and forest monodominant (HUETE et al., 2002).

Otherwise, only observing the correlations obtained by the estimated values with measured $\mathrm{ET}_{24 \mathrm{~h}}$ by the method of Bowen ratio the correlations values are higher than found in the proposals MSAVIaround for CAM $(r=0.75)$, all proposals for EF, for LAI MF $(r=0.86)$, with NDVI and SAVI to SINOP $(r=0.84)$, with $p-$ value $<0.05$ (Table 2 ).

\section{CONCLUSIONS}

The automatic selection of the pixels hot and cold was successful, with correlations exceeding 0.83 for estimates of sensible heat flux and 0.75 for estimates of evapotranspiration. The daily sensible heat flux $\left(\mathrm{H}_{24 h}\right)$ and daily evapotranspiration $\left(\mathrm{ET}_{24 \mathrm{~h}}\right)$ measured and estimated ranged according to different classes of surface coverage. The daily sensible heat flux $\left(\mathrm{H}_{24 h}\right)$ estimated based on automated identification of hot and cold pixels, which showed better performance in terms of index were: NDVI, for CAM, SAVI, for EF, NDVI $I_{\text {around }}$ for MF and the proposed Bastiaanssen to SINOP.

The identification of hot and cold pixels, using the methodology by similarity of neighboring pixels, using the average of pixels ( $3 \times 3$ grids) showed the highest correlations for the sensible heat flux in the study areas. The LAI had the best indicator in the automated identification of hot and cold pixels to estimate the daily evapotranspiration $\left(\mathrm{ET}_{24 h}\right)$.

Our results have important implications for modeling $\mathrm{H}_{24 \mathrm{~h}}$ and $\mathrm{ET}_{24 \mathrm{~h}}$ on regional scale. The results presented here also highlight some of the complexities in validating satellite products. While we point out some potential biases in the automatization of SEBAL to estimate $\mathrm{H}_{24 h}$ and $\mathrm{ET}_{24 h}$, further study over a variety of Brazilian Ecosystems are needed to quantitatively assess the SEBAL in order to improve their accuracy.

\section{REFERENCES}

ALLEN, R.; BASTIAANSSEN, W.; WATERS, R.; TASUMI, M.; TREZZA, R.. Surface energy balance algorithms for land (SEBAL), Idaho implementation - Allen, R. G. Assessing integrity of weather data for use in reference evapotranspiration estimation. Journal of Irrigation and Drainage Engineering, v.2, p.97-106, 2002. DOI: https://doi.org/10.1061/(ASCE)0733-9437(1996)122:2(97) 
ALLEN, R. G.; TASUMI, M.; TREZZA, R.. Satellite-based energy balance for mapping evapotranspiration with internalized calibration (METRIC)-Model. Journal of Irrigation and Drainage Engineering, v.133, n.4, p.380-394, 2007a. DOI: https://doi.org/10.1061/(ASCE)0733-9437(2007)133:4(380)

ALLEN, R. G.; TASUMI, M.; MORSE, A.; TREZZA, R.; WRIGHT, J. L.; BASTIAANSSEN, W.; KRAMBER, W.; LORITE-TORRES, I.; ROBISON, C. W.. Satellite-based energy balance for mapping evapotranspiration with internalized calibration (METRIC)Applications. Journal of Irrigation and Drainage Engineering, v.133, n.4, p.395-406, 2007b. DOI: http://doi.org/10.1061/(ASCE)0733-9437(2007)133:4(380)

ALLEN, R.; IRMAK, A.; TREZZA, R.; HENDRICKX, J. M. H.; BASTIAANSSEN. W.; KJAERSGAARD, J.. Satellite-based ET estimation in agriculture using SEBAL and METRIC. Hydrological Processes, v.25, p.4011-4027, 2011. DOI: https://doi.org/10.1002/hyp.8408

ANDRADE, R. G.; SEDIYAMA, G. C.; PAZ, A. R.; LIMA, E. P.; FACCO, A. G.. Geotecnologias aplicadas à avaliação de parâmetros biofísicos do Pantanal. Pesquisa Agropecuária Brasileira, v.47, p.1227-1234, 2012. DOI: http://doi.org/10.1590/S0100-204X2012000900007

BASTIAANSSEN, W. G. M.; MENENTI, M.; FEDDES, R. A.; HOLTSLANG, A. A.. A remote sensing surface energy balance algorithm for land (SEBAL): 1 . Formulation. Journal of Hydrology, v.212-213, p.198-212, 1998a. DOI: https://doi.org/10.1016/S0022-1694(98)00253-4

BASTIAANSSEN, W. G. M.; PELGRUM, H.; WANG, J.; MA, Y.; MORENO, J. F.; ROERINK, G. F.; VAN DER WAL, T.. A remote sensing surface energy balance algorithm for land (SEBAL).: Part 2: Validation. Journal of hydrology, v.212, p.213-229, 1998b. DOI: https://doi.org/10.1016/S0022-1694(98)002546 .

BASTIAANSSEN, W. G. M. SEBAL - Based sensible and latent heat fluxes in the irrigated Gediz Basin, Turkey. Journal of Hydrology, v.229, p.87-100, 2000. DOI: https://doi.org/10.1016/S0022-1694(99)00202-4.

BILLESBACH, D. P.; ARKEBAUER, T. J.. First long-term, direct measurementsof evapotranspiration and surface water balance in the Nebraska Sand-Hills. Agric. For. Meteorol., v.156, p.104-110, 2012. DOI:

http://dx.doi.org/10.1016/i.agrformet.2012.01.001

BIUDES, M. S.; CAMPELO JÚNIOR, J. H.; NOGUEIRA, J. S.; SANCHES, L.. Estimativa do balanço de energia em cambarazal e pastagem no norte do Pantanal pelo método da razão de Bowen. Revista Brasileira de Meteorologia, v.2, p.135-143, 2009. DOI: https://doi.org/10.1590/S010277862009000200003.

BIUDES, M. S.; NOGUEIRA, J. S.; DALMAGRO, H. J.; MACHADO, N. G.; DANELICHEN, V. H. M.; SOUZA, M. C.. Mudança no microclima provocada pela conversão de uma floresta de cambará em pastagem no norte do Pantanal. Revista de Ciências Agro-Ambientais, v.1, p.61-68, 2012.

BIUDES, M. S.; VOURLITIS, G. L.; MACHADO, N. G.; ARRUDA, P. H. Z.; NEVES, G. A. R.; LOBO, F. A.; NEALE, C. M.

U.; NOGUEIRA, J. S.. Patterns of energy exchange for tropical ecosystems across a climate gradient in Mato Grosso, Brazil.
Agricultural and Forest Meteorology, v.202, p.112-124, 2014. DOI: https://doi.org/10.1016/i.agrformet.2014.12.008

BRÉDA, N. J. J. Ground-based measurements of leaf área index: a review of methods, intruments and current controversies. Journal of Experimental Botany, v.54, n.393, p.2403-2417, 2003. DOI: http://doi.org/10.1093/jxb/erg263

BRUTSAERT, W.. Evaporation into the Atmosphere, Reidel. Dordrecht, 1982.

CHEHBOUNI, A.; SEEN, D. L. O.; NJOKU, E. G.; MONTENY, B. Examination of the difference between radiative and aerodynamic surface temperatures over sparsely vegetated surfaces, Remote Sens. Environ., v.58, p.177-186, 1996. DOI: https://doi.org/10.1016/S0034-4257(96)00037-5

DICKEN, U.; COHEN, S.; TANNY, J.. Examination of the Bowen ratio energy balancetechnique for evapotranspiration estimates in screenhouses. Biosyst. Eng., v.114, p.397405, 2013. DOI:

http://dx.doi.org/10.1016/i.biosystemseng.2012.11.001

DREXLER, J. Z.; SNYDER, R. L.; SPANO, D.; PAW, U. K. T.. A review of models andmicrometeorological methods used to estimate wetland evapotranspiration. Hydrol. Process., v.18, n.11, p.2071-2101, 2004. DOI: http://dx.doi.org/10.1002/hyp.1462

FEILHAUER, H.; SCHMIDTLEIN, S.. Mapping continuous fields of forest a- and b-diversity. Applied Vegetation Science, v.12, p.429439, 2009. Dol: https://doi.org/10.1111/j.1654109X.2009.01037.x

GAO, Z. Q.; LIU, C. S.; GAO, W.; CHANG, N. B..A coupled remote sensing and the Surface Energy Balance with Topography Algorithm (SEBTA) to estimate actual evapotranspiration over heterogeneous terrain. Hydrol. Earth Syst. Sci., v.15, p.119-139, 2011. DOI: https://doi.org/10.5194/hess-15-119-2011

GOWDA, P. H.; CHAVEZ J. L.; COLAIZZI, P. D.; EVETT, S. R.; HOWELL, T. A.; TOLK, J. A.. ET mapping for agricultural water management: Present status and challenges. Irrig. Sci., v.26, n.3, p.223-237, 2009. DOI: https://doi.org/10.1007/s00271007-0088-6

HALL, F. G.; HEUMMRICH, K. F.; GOETZ, S. J.; SELLERS, P. J.; NICKESON, J. E.. Satellite remote sensing of surface energy balance: success, failures and unsolved issues in FIFE. J. Geophys. Res., v.97, n.D17, p.19,061-19,089, 1992. DOI: https://doi.org/10.1029/92JD02189

HU, S.; ZHAO, C.; LI, J.; WANG, F.; CHEN, Y.. Discussion and reassessment of themethod used for accepting or rejecting data observed by a Bowen ratio system. Hydrol. Process., 2013. DOI: http://dx.doi.org/10.1002/hyp.9962

HUETE, A. R.; LIU, H. Q.; BATCHILY, K.; VAN LEEUWEN, W.. A comparison of vegetation indices over a global set of TM images for EOS-MODIS. Remote Sensing of Environment, v.59, p.440-451, 1997. DOI: https://doi.org/10.1016/S00344257(96)00112-5

HUETE, A.; JUSTICE, C.; VAN LEEUWEN, W.. MODIS vegetation index (MOD 13): algorithm theoretical basis document. Version 3. Washington: National Aeronautics and 
Space Administration, 1999.

HUETE, A.; DIDAN, K.; MIURA, T.; RODRIGUEZ, E. P.; GAO, X.; FERREIRA, L. G.. Overview of the radiometric and biophysical performance of the MODIS vegetation indices. Remote Sensing of Environment, v.83, p.195-213, 2002. DOI: https://doi.org/10.1016/S0034-4257(02)00096-2

KJAERSGAARD, J. H.; ALLEN, R. G.; GARCIA, M.; KRAMBER, W.; TREZZA, R.. Automated Selection of Anchor Pixels for Landsat based Evapotranspiration Estimation. World Environmental and Water Resources Congress: Great Rivers. ASCE, 2009. DOI: https://doi.org/10.1061/41036(342)442

KUSTAS, W. P.; DAUGHTRY, C. S. T.. Estimation of the soil heat flux/net radiation ratio from multispectral data. Agric. For. Meteor., v.49, p.205-223, 1990. DOI: https://doi.org/10.1016/0168-1923(90)90033-3

LEIVAS, J. F.; ANDRADE, R. G., NOGUEIRA, F. S.; BOLFE, E. L.. Estimativa da Evapotranspiração em áreas com diferentes características ambientais utilizando o algoritmo Sebal. In: CONGRESSO BRASILEIRO DE AGROMETEOROLOGIA, 17. Anais. Guarapari: Centro de Turismo de Guarapari, 2011.

MAAS, S.; RAJAN, N.. Estimating ground cover of field crops using medium resolution multispectral satellite imagery. Agronomy Journal, v.100, n.2, p.320-327, 2008. DOI: https://doi.org/10.2134/agroni2007.0140

MENDONÇA, J. C.; SOUZA, E. F.; BOUHID, A.; SILVA, B. B.; FERREIRA, F. J.. Estimativa do fluxo de calor sensível utilizando o algoritmo SEBAL e imagens MODIS para a região Norte Fluminense, RJ. Revista Brasileira de Meteorologia, v.27, n.1, p.85-94, 2012. DOI: https://doi.org/10.1590/S0102-77862012000100009

MENENTI, M.; CHOUDHURY, B. J.. Parameterization of land surface evapotranspiration using a location dependent potential evapotranspiration and surface temperature range. Exchange Processes at the Land Surface for a Range of Space and Time Scales, v.212, p.561-568, 1993.

MOORE, C. J.; FISCH, G.. Estimating heat storage in Amazonian tropical forest. Agric. For. Meteorol., v.38, n.1-3, p.147-168, 1986. DOI: http://dx.doi.org/10.1016/0168$\underline{1923(86) 90055-9}$

MONTEITH, J. L.. Principles of Environmental Physics. London: Edward Arnold, 1973.

MU, Q.; ZHAO, M.; RUNNING, S. W.. Improvements to a MODIS global terrestrial evapotranspiration algorithm. Remote Sensing of Environment. 8: 1781-1800. Numerical Terradynamic Simulation Group, Department of Ecosystem and Conservation Sciences, The University of Montana, Missoula, MT 59812, 2011. DOI: https://doi.org/10.1016/i.rse.2011.02.019

NORMAN, J. M., KUSTAS, W. P.; HUMES, K. S.. A two-source approach for estimating soil and vegetation energy fluxes from observations of directional radiometric surface temperature. Agric. For. Meteor., v.77, p.263-293, 1995. DOI: https://doi.org/10.1016/0168-1923(95)02265-Y

ORTEGA-FARIAS, S. O.; CUENCA, R. H.; EK, M.. Daytime variation of sensible heat flux estimated by the bulk aerodynamic method over a grass canopy. Agric. For.

Meteorol., v.81, p.131-143, 1996. DOI:

http://dx.doi.org/10.1016/0168-1923(95)02278-3

PEREZ, P. J.; CASTELLVI, F.; IBAÑEZ, M.; ROSELL, J. I.. Assessment of reliability of Bowen ratio method for partitioning fluxes. Agricultural and Forest Meteorology, v.97, p.141-150, 1999. DOI: https://doi.org/10.1016/S01681923(99)00080-5

PRIANTE FILHO, N.; VOURLITIS, G. L.; HAYASHI, M. M. S. NOGUEIRA, J. S.; CAMPELO JÚNIOR, J. H.; NUNES, P. C.; SOUZA, L. S.; COUTO, E. G.; HOEGER, W.; RAITER, F.; TRIENWEILER, J. L.; MIRANDA, E. J.; PRIANTE, P. C.; FRITZEN C. L.; LACERDA, M.; PEREIRA, L. C.; BIUDES, M. S.; SULI, G. S.; SHIRAIWA, S.; PAULO, S. R.; SILVEIRA, M.. Comparison of the mass and energy exchange of a pasture and a mature transitional tropical forest of the southern Amazon Basin durin a seasonal transition. Global Change Biology, v.10, p.863-876, 2004. DOI: https://doi.org/10.1111/j.15298817.2003.00775.x

RADAMBRASIL. Levantamentos dos Recursos Naturais Ministério das Minas de Energia. Secretaria Geral. Projeto RADAMBRASIL. Folha SD 21 Cuiabá. Rio de Janeiro, 1982.

ROCCHINI, D.; NETELER, M.. Let the four freedoms paradigm apply to ecology. Trends in Ecology and Evolution, v.27, p.310-311, 2012. DOI: https://doi.org/10.1016/i.tree.2012.03.009

RUHOFF, A. L.; PAZ, A. R.; COLLISCHONN, W.; ARAGAO, L. E. O. C.; ROCHA, H. R.; MALHI, Y. A.. MODIS-Based Energy Balance to Estimate Evapotranspiration for Clear-Sky Days in Brazilian Tropical Savannas. Remote Sens., v.4, p.703-725, 2012. DOI: https://doi.org/10.3390/rs4030703

SENAY, G. B.; BUDDE, M.; VERDIN, J. P.; MELESSE, A. M.. A coupled remote sensing and simplified surface energy balance approach (SSEB) to estimate actual evapotranspiration from irrigated fields. Sensors, v.7, p.9791000, 2007. DOI: https://doi.org/10.3390/s7060979

SU, Z.. The surface energy balance system (SEBS) for estimation of turbulent fluxes. Hydrol. Earth Systems Sci., v.6, p.85-99, 2002. DOI: https://doi.org/10.5194/hess-6-85$\underline{2002}$

UNLAND, H. E.; HOUSER, P. R.; SHUTTLEWORTH, W. J.; YANG, Z. L.. Surface flux measure-ment and modelling at a semi-arid Sonoran Desert site. Agric. For. Meteorol., v.82, p.119-153, 1996. DOI: http://dx.doi.org/10.1016/01681923(96)02330-1

UN-WATER. Status report on integrated water resources management and water efficiency plans. In: SESSION OF THE COMMISSION ON SUSTAINABLE DEVELOPMENT, 16. Anais. 2008.

VOURLITIS, G. L.; LOBO, F. A.; ZEIHLOFER, P.; NOGUEIRA, J. S.. Temporal patterns of net $\mathrm{CO} 2$ exchange for a tropical semi-deciduous forest of the southern Amazon Basin. Journal of Geophysical Research, v.116, n.G03029, 2011. DOI: https://doi.org/10.1029/2010JG001524

VOURLITIS, G. L.; LOBO, F. A.; LAWRENCE, S.; LUCENA, I. C.; BORGES JUNIOR, O. B.; DALMAGRO, H. J.; ORTIZ, C. E. R.; 
NOGUEIRA, J. S.. Variations in stand structure and diversity alonga soil fertility gradient in a Brazilian savanna (Cerrado) in southern Mato Grosso. Soil Sci. Soc. Am. J., v.77, p.13701379, 2013. DOI: http://dx.doi.org/10.2136/sssaj2012.0336

VÖRÖSMARTY, C. J.; FEDERER, C. A.; SCHLOSS, A. L.. Potential evaporation function compared on US watersheds: Possible implication for global-scale water balance and terrestrial ecosystem. Journal of Hydrology, n.207, p.147169, 1998. DOI: https://doi.org/10.1016/S0022$\underline{1694(98) 00109-7}$

VÖRÖSMARTY, C. J.; MCINTYRE, P. B.; GESSNER, M. O.; DUDGEON, D.; PRUSEVICH, A.; GREEN, P.. Global threats to human water security and river biodiversity. Nature, v.467, p.555-561, 2010. DOI: http://doi.org/10.1038/nature09549
ZEILHOFER, P.. Soil mapping in the Pantanal of Mato Grosso, Brazil usingmultitemporal Landsat TM data. Wetl. Ecol. Manage, v.14, n.5, p.445-461, 2006. DOI: http://dx.doi.org/10.1007/s11273-006-0007-2

ZHAO, M.; RUNNING, S. W.. Drought-induced reduction in global terrestrial net primary production from 2000 through 2009. Science, v.329, p.940-943, 2010. DOI: http://doi.org/10.1126/science.1192666

ZIBOGNON, M.; CRAGO, R.; SULEIMAN, A.. Conversion of radiometric to aerodynamic surface temperature with an anisothermal canopy model. Resources Research, v.38, n.6, p.1067, 2002. DOI: https://doi.org/10.1029/2001WR000484

A CBPC - Companhia Brasileira de Produção Científica (CNPJ: 11.221.422/0001-03) detém os direitos materiais desta publicação. Os direitos referem-se à publicação do trabalho em qualquer parte do mundo, incluindo os direitos às renovações, expansões e disseminações da contribuição, bem como outros direitos subsidiários. Todos os trabalhos publicados eletronicamente poderão posteriormente ser publicados em coletâneas impressas sob coordenação da Sustenere Publishing, da Companhia Brasileira de Produção Científica e seus parceiros autorizados. Os (as) autores (as) preservam os direitos autorais, mas não têm permissão para a publicação da contribuição em outro meio, impresso ou digital, em português ou em tradução. 